Original Article

\title{
Environmental characteristics, nutritional and executive functions in children of 6 to 7 years
}

\author{
Características ambientais, funções nutricionais e executivas em crianças de 6 a 7 anos
}

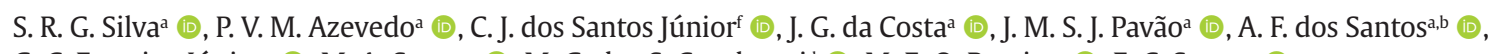

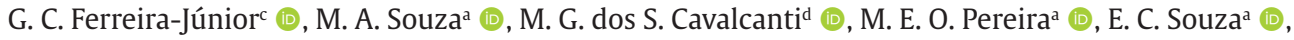

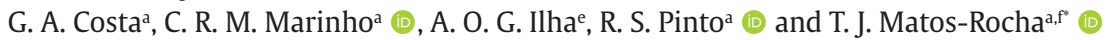

${ }^{a}$ Centro Universitário CESMAC, Maceió, AL, Brasil

bUniversidade Estadual de Alagoas - UNEAL, Arapiraca, AL, Brasil

Instituto Federal de Educação, Ciência e Tecnologia do Acre - IFAC, Xapuri, AC, Brasil

dUniversidade Federal da Paraíba - UFPB, João Pessoa, PB, Brasil

eUniversidade de São Paulo - USP, Faculdade de Medicina, Hospital das Clínicas - HCFMUSP, Laboratório de Lipides - LIM10, São Paulo, SP, Brasil

fUniversidade Estadual de Ciências da Saúde de Alagoas - UNCISAL, Maceió, AL, Brasil

\begin{abstract}
This study aimed to analyze the socio-environmental characteristics, executive and nutritional functions in children aged 6 to 7 years, from public schools in Alagoas, Brazil. A quantitative, cross-sectional and descriptive study was performed involving 64 children of the mentioned age group, from public schools located in Alagoas: Maceió, on the coast; Major Isidoro, in the hinterland and Palmeira dos Índios, in the country. Such analyzes were made through the application of neuropsychological tests and anthropometric assessment with children and food and socio-environmental surveys with their parents. As for the type of housing, $100 \%$ were made of masonry, with a bathroom present in $98.4 \%$. All children reported with the habit of bathing in the river / lagoon, presented some pathology. There was no significant difference between cities in terms of the sociodemographic characteristics evaluated, with the same result occurring with the factors associated with the occurrence of diseases in children. The subtests of WISC-IV, were below the average in all municipalities, and the TAC and SCC were classified within the average. However, even though the ranking were divided between below average and average, it is possible to identify from the subtests of WISC-IV, that the general IQ showed a cognitive level below the average. There was also no significant difference in the anthropometric assessment (weight, height, BMI and IMCI) between the evaluated students. The average weight was $23.3 \mathrm{~kg}$ to $25 \mathrm{~kg}$, the height between $1.23 \mathrm{~m}$ to $1.24 \mathrm{~m}$, the BMI between 16.4 to 17; the IMCI from 2.8 to 3.0. Children were classified within the average. Regarding micronutrients (Ca, Fe, $\mathrm{K}, \mathrm{Mg}$ and $\mathrm{Na}$, and vitamins A, C, D, B1, B9 and B12) and calories, there was also no significant difference between the cities evaluated. The same occurred with macronutrients (proteins, carbohydrates and lipids). This study showed that in general there was no difference between the students of the three municipalities. Probably, even though they are all public schools and from different cities, children have similar social conditions.
\end{abstract}

Keywords: child, executive function, nutrition, socio-environmental.

\begin{abstract}
Resumo
Este estudo teve como objetivo analisar as características socioambientais, funções executivas e nutricionais de crianças de 6 a 7 anos, de escolas públicas de Alagoas, Brasil. Foi realizado um estudo quantitativo, transversal e descritivo envolvendo 64 crianças, na referida faixa etária, de escolas públicas localizadas em Alagoas: Maceió, no litoral; Major Isidoro, no sertão e Palmeira dos Índios, no país. Tais análises foram feitas por meio da aplicação de testes neuropsicológicos e avaliação antropométrica com crianças e inquéritos alimentares e socioambientais com seus pais. Quanto ao tipo de habitação, $100 \%$ eram de alvenaria, com banheiro presente em 98,4\%. Todas as crianças relataram o hábito de tomar banho no rio / lagoa, apresentavam alguma patologia. Não houve diferença significativa entre os municípios quanto às características sociodemográficas avaliadas, ocorrendo o mesmo resultado com os fatores associados à ocorrência de doenças em crianças. Os subtestes do WISC-IV, ficaram abaixo da média em todos os municípios, e o TAC e SCC foram classificados dentro da média. Porém, mesmo que a classificação tenha sido dividida entre abaixo da média e média, é possível identificar a partir dos subtestes do WISC-IV, que o QI geral apresentou um nível cognitivo abaixo da média. Também não houve diferença significativa na avaliação antropométrica (peso, altura, IMC e AIDPI) entre os alunos avaliados. O peso médio foi de 23,3 kg a
\end{abstract}

*e-mail: tmatosrocha@cesmac.edu.br

Received: December 15, 2020 - Accepted: April 29,2021

This is an Open Access article distributed under the terms of the Creative Commons Attribution License, which permits unrestricted use, distribution, and reproduction in any medium, provided the original work is properly cited. 
$25 \mathrm{~kg}$, a altura entre 1,23 ma 1,24 m, o IMC entre 16,4 a 17; A AIDPI de 2.8 a 3.0. As crianças foram classificadas dentro da média. Em relação aos micronutrientes (Ca, Fe, K, Mg e Na e vitaminas A, C, D, B1, B9 e B12) e calorias, também não houve diferença significativa entre os municípios avaliados. $O$ mesmo ocorreu com os macronutrientes (proteínas, carboidratos e lipídios). Este estudo mostrou que de maneira geral não houve diferença entre os alunos dos três municípios. Provavelmente, mesmo sendo todas escolas públicas e de diferentes cidades, as crianças têm condições sociais semelhantes.

Palavras-chave: criança, função executiva, nutrição, socioambiental.

\section{Introduction}

Executive functions are a set of skills that enable careful thinking, intended to achieve a particular goal. When operational, executive function allows the individual to reflect before acting, develop different projects mentally, solve unexpected challenges, to think from different perspectives, to reconsider opinions and to avoid distractions. Thus, these skills are essential to make decisions, live and think autonomously. Its main development occurs from birth to six years of age, a period that corresponds to early childhood, and is strongly influenced by the quality and quantity of experiences that children can have, concerning biological and emotional aspects (Baggeta \& Alexander, 2016; Bardikoff \& Sabbagh, 2017). In Brazil, the population's health and nutrition circunstances has suffered significant changes in the last 35 years, characterizing the so-called epidemiological and nutritional transition. This process of rapid change transformed the geographical, social and biological distribution of almost every disease and death causes. Particularly in the area of nutrition, the sharp decline in protein-energy malnutrition (PEM) in children and women and the substantial increase in the prevalence of obesity in these same groups (Mondini and Gimeno, 2011; Monteiro et al., 2009).

The infant mortality rate is an important parameter, as it reflects the conditions of socioeconomic development and environmental infrastructure, such as access to drinking water and basic sanitation for a population, in addition to access and quality to the services available for maternal and child health care (Brasil, 2011). About 6.6 million children died in 2010 due to malnutrition (Turab et al., 2014). The state of Alagoas, according to the latest survey by the Human Development Atlas of 2013, using the human development index by municipalities (MHDI) for 2010 as the basis, had the last position among all federative units in Brazil, with an MHDI of 0.641. The infant mortality rate is one of the most striking indicators in the state. In chronological order, infant mortality rates in Alagoas were 74.5 in 1991; from 49.0 in 2000 and 28.4 in 2010 (Brasil, 2013).

Although Brazil has met the goals of the United Nations Millennium Development Goals, according to which infant mortality in the country should be below 17.9 deaths per thousand in 2015, the numbers in the state of Alagoas are still alarming, especially when mortality data up to 5 years of age are analyzed, which show rates of 30.1 deaths per thousand live births (Brasil, 2013). Studies show that malnutrition affects more than 165 million children worldwide, with a prevalence rate in Africa of around 20 to $35 \%$. Malnutrition among children is an indication of social inequalities, chronic diseases, deficits in executive functions, premature death and even reduced income in adulthood, according to Sanou et al. (2018). Jombo and Dabit (2018) complements this idea by saying that the consequences of poor nutrition include an increase in the proportion of children with cognitive impairment, causing problems in physical, mental and social development.

These are lines that reflect children's behavior and expose how susceptible the child is to situations of vulnerability and, therefore,placing them at risk. In addition to what was mentioned, factors such as maternal depression during pregnancy and exposure to violence also interfere in this infant's neurodevelopmental health (Donald et al., 2018). There are many means of research on executive functions (EF) in the child context in conjunction with socio-environmental, food and neuropsychological issues. From studies on human development, the arguments of psychology are based on an effort to examine the subject from birth until reaching a certain stage of maturation, perceiving a certain stability. With such reasoning, Piaget was concerned with the procedural instruments of thought and with these, there is an understanding of logic, which is conceived by a process of balance in which the organism meets logical thinking, being conditio sine qua non that healthy eating is guaranteed (Terra, 2010). Cognitive psychology holds that only at the age of primary school will the child be able to move from arguments to conclusions in their conversations, making associations of minor concepts to major ones. For this, it will be necessary that this child has a balanced nutritional development (Elkind, 1957).

Malnutrition is a factor that significantly interferes with memory and, therefore, with cognitive aspects. With an affected memory, even moderately, there is a decrease in the intellectual progress of the developing child, causing feelings of worthlessness, the desire to not return to the school environment, insecurity and the belief of having less intelligence. The infant often feels inferior by his colleagues for not accompanying them in school activities, pointing to feelings of shame and disinterest in studies. In view of such positions, attention should be paid to the triad in which the human being is invariably inserted: the biological, socio-environmental and psychological fields. When analyzing this triad, it is important to perform a nutritional study of children aged 6 to 7 years through food surveys with their parents and anthropometric analyzes, to check if there is any evidence of poor diet that may interfere with the nutritional or cognitive process. There is a growing concern with the socio-environmental conditions in which children live in Brazil, about their characteristics and what they can cause to the infant; as well as other investigative areas, such as executive functions and nutritional characteristics. The study of 
these characteristics in children from the coastal, sertão and hindland regions of Alagoas is important for public policy planning, given the lack of data in the literature on this subject. Thus, the work aimed to evaluate the socioenvironmental characteristics, executive and nutritional functions of children aged 6 to 7 years in Alagoas, covering the coastal, rural and backlands.

\section{Material and methods}

\subsection{Ethical procedures}

This work was approved by the Research Ethics Committee (CEP) of Centro Universitário Cesmac, under CAAEE number: 79331117800000039.

\subsection{Type of study}

A quantitative, descriptive and cross-sectional study was performed from February to July 2018.

\subsection{Sample calculation and research subjects}

The sample consisted of 64 children aged 6 to 7 years in public schools in Maceió-AL (city 1), Major Isidoro-AL (city 2) and Palmeira dos Índios-AL (city 3). The schools had about 35 children in this age group, which represented a small ammount of the total number of students enrolled in general in each school distributed in their respective cities. We chose to define the number of infants in this stage of the study per maturation cycle regarding their age groups, for greater reliability in the results. The planning of the sample size took into account the Type I error. To dimension the sample, a standard error of 3 was used, a test power of $95 \%$ and an $\alpha$ of $5 \%$. A sample of 30 individuals (for each school) was arrived at. Considering the losses in the execution of the study, it was decided to include 25 individuals per school. However, despite the ideal average of the participants being 75 children, only 64 were included, due to the remaining 11 not being included in the inclusion criteria. We chose to identify each participant with a chosen number, for ethical reasons of secrecy and confidentiality.

\subsection{Procedures}

The research was performed in 3 public schools, one in each region of the State of Alagoas (coastal, rural and hinterland), aimed at investigating the socio-environmental characteristics, executive and nutritional functions of children aged 6 to 7 years. We opted to investigate such regions of Alagoas, as there has not yet been a study of such characteristics that encompassed these regions in Alagoas. Soon after, the participants and their guardians were invited to sign the Informed Consent Form after careful reading and clarified doubts about the study.

\subsection{Social and environmental aspects}

A questionnaire on socio-environmental aspects was carried out with the 64 parents / guardians of the children in an environment reserved from interference from the external environment due to confidentiality and confidentiality, with the aim of obtaining data, which were collected on some aspects such as: basic sanitation, garbage collection, type of housing, among others.

\subsection{Executive function tests}

The Neuropsychological tests were explained clear and objectively to each participant, with accessible language for a better understanding of the tasks. After applying each test used, the scores recorded during the tests were added to obtain the results of each one. As instruments to identify cognitive levels, the tests were: Davis Wechsler's Wechsler Intelligence Scale for Children (WISC IV) in the 2013 version, which aimed to assess cognitive performance, intellectual capacity and the problem solving process in children, with subtests (Wechsler, 2013):

a. Digits - these are tasks related to the ability to concentrate. Digit repetition tasks in direct and indirect order. The first evaluated the attentional capacity, that is, the amount of stimuli that was able to capture the memory retention capacity at a given moment. The repetition of inverse digits, analyzed the mental organization with series that evaluated working memory. The material used was the Technical Instruction Manual for Application and Evaluation and the Registration Protocol.

It was a test aimed at children from 6 to 16 years old, which had two items: the direct order and the reverse order, the reverse order with one more item, which was the example for the child to understand the task before carrying it out. It was said / or repeated to the child until he understood at the beginning of the test as instructed by the statement: "I will say some numbers. Listen carefully and, as soon as I finish, repeat exactly what I say. Just say what I said ". The examiner spoke slowly and in a good tone: "two, nine", for example, and asked to repeat this same sequence. A second sequence of the same degree of difficulty was said. When the child got it right, the examiner was able to start the test. If the child had not got it right, it was explained again in an even more accessible language. However, a few did not get it right, the application was aborted and noted in the Registration Protocol. After the Direct Order stage, the Reverse Order followed. It showed the example so that the examinee could follow the same line of reasoning: He was asked to repeat numbers 8 - 2 in reverse order, so he had to say: 2 - 8 . This was followed with the same evaluative form when the child got the words right or not. This test did not have a determined time for its performance, but once 3 consecutive sequences were missed, the test was ended and the total of correct answers was added (which corresponded to the total of correct answers). Inverse Order was applied, regardless of the examinee's performance in the Direct Order. Each item offered two attempts, which were applied even when the examinee was successful or not in the first attempt .

After the application of Digits, the Code Subtest was applied (test for children aged 6 - 7 years) - which assesses visual attention combined with the speed of information processing. Only Code A was used, as it simplified the non-verbal reasoning for the age group chosen as the " $n$ " in the present study. The examiner 
pointed to the printed images (named "keys") at the top of the page and said: "Here are some shapes (circle, star, square, etc.) with signs inside them. Each shape has its own sign "(pointed to each shape). In each exemplified item, the examiner said: "Here are some empty shapes (circle, star, square etc., only with the outline). You will fill in these forms like this ", as they were printed above previously explained. Soon after, he pointed to the first example item (circle) and said: "See how I do it. Here we have a circle (hollow). This circle up here (pointed to the circle in the part where the images were in the "key"). And he continued saying: "[...] there are two lines that look like this (parallel lines horizontally drawn inside the circle). So, I draw two lines here in this circle ". And he designed it so that the examiner could see how to proceed during the test. He had 2 minutes to complete the task of filling in the images as in the example of the key and it was explained about this time to him before the test. When the two minutes were up, even if the child was not finished, he was told that the time was up and the examiner praised the child for the task, thanking him for taking another test. When the child finished before two minutes, it was noted how long the task was carried out and the bonus points according to the Manual, by number of correct answers. After the test, the examiner checked which images corresponded to those of the "key" and noted the number of correct answers for the sum of the gross score and obtaining the test result.

It is worth mentioning that the time recording was timed right after the verbalization of the last word in the instructions and stopped when the child finished filling out the figures, or with the end of the 2 minute time limit.

b. Matrix Reasoning Subtest (only items from A-C due to the children's age group) - which evaluates non-verbal abstract reasoning. Subtest for children 6 - 8 years old. The test application was interrupted after 4 consecutive errors. The recording of scores was performed at the end of the test in the Registration Protocol to obtain its result. The Stimulus Book was placed closed on the table, with a spiral facing the child. The examiner opened the example A page of this subtest and said: "Look at these figures. Which of these here (did you run your finger over the answer options), go here? " (pointed to the space that had a question mark). If the child had pointed correctly, the examiner would say: "Very well. Let's do another one ", and apply example B and then example $C$. The examiner repeated the operation and after realizing that the examinee understood what the subsequent examples were like, starting the test. The examinee had to identify the next figures by himself until he finished them. The examiner wrote down on an answer sheet, that is, a sieve that was represented only by the first column due to the age of the children under study), circling which item the child identified, to obtain the gross test score.

c. SEABRA (by Alessandra Seabra, version 2012) Neuropsychological assessment of executive functions (volumes 1 and 2) - Interprets an individual's performance concerning what is expected for their level of development, concerning attention and executive functions (Seabra, 2012a). Volume 1 - Cancel by Attention Test (CAT) has three printed matrices with different types of stimuli in which the examinee marks the figure. The child marked all stimuli similar to the target stimulus previously determined. At all stages, the examiner instructed her through examples of the activity. The test evaluated Concentrated Attention at first, then Divided Attention and finally, Alternate Attention. In the first, the child marked the figures concerning the example A provided by the applicator (which was a "cross"), that is, when he saw a cross, he marked it. In the second, the examinee marked every time he visualized a cross and a star in the same sequence in example B and in the last step, for each line corresponding to the figure in example $C$ on the left, she marked the similar figures. At the end of each subtest, the examiner praised the child and thanked him for his participation. The test was evaluated using the sum of the scores to obtain its general result.

The Volume 2 analyzes oral language with the subtest of Spoken Sentence Comprehension (SSC), which measures the listening comprehension ability (Seabra, 2012b). The subtest contains 6 training items, with 40 test items (which are arranged by drawings) that the examinee identifies according to the statements dictated by the examiner. The tester spoke a sentence and the child identified the figure concerning the statement made by the examiner item by item, marking the figure with an " $\mathrm{X}$ ". It was possible to repeat it to the child if the examiner had realized that he did not understand. The applicator said to the subject: "In this game, for each sentence that I speak there are 5 figures. I want you to mark an " $\mathrm{X}$ " in the figure that most closely matches this phrase ". In one example, the applicator said: "among these musical instruments, only one is the guitar. What are the figures that we have?". The examiner explained clearly and objectively what it was like to identify the figure corresponding to the one he had dictated to the child. Only after the child understood what the test worked was it applied. The examinee chose from among the 5 alternative figures, the one corresponding to the sentence read by the examiner. Sometimes, the examiner was wrong, but after the test, the examiner no longer guided the task, leaving the child to do it for itself.

For this test, there was no time limit established to answer it, although the average application lasted about 20 minutes. The test is aimed at children from 6 to 11 years of elementary school, a population for which it was more suitable for the test. After applications were completed, the examiner would check the score made by each child to obtain the result. It is worth noting that all the phrases suggested by the tests mentioned above could be replaced by an even more accessible and playful language so that the child could have better understood each proposed item, doing it with greater pleasure. All tests were performed individually in an appropriate room reserved for interference from outside. 


\subsection{Nutritional scrutiny}

\subsubsection{Anthropometric Assessment}

The variables used to perform anthropometric measurements were weight, height and age according to the World Health Organization (Cavalheiro et al., 2020). For the weighing of children, a portable digital scale (maximum weight $150 \mathrm{~kg}$ ) was used, in which the children were instructed to remove their shoes and jackets. Height was measured with a portable Sanny ${ }^{\circledR}$ stadiometer. The data were interpreted, according to the Ministry of Health's recommendation for children between 5 and 10 years old, by the Body Mass Index ( $\mid$ ) which expresses the relationship between the child's weight and the square of height. Another parameter used was the cut-off points for Height for Age used for children from 0 to 10 years old, which expresses the linear growth of children. The index that best shows the possible cumulative effects of adverse situations to the child's growth, was considered the indicator of greater sensitivity to measure the quality of life of the population (Brasil, 2011).

\subsection{2. $24 \mathrm{~h}$ recall}

In this study, a 24-hour food recall was applied to the guardians of the children evaluated. The 24-hour recall consists of defining and quantifying all the food and beverages consumed in the 24 -hour period preceding the interview. Questioning about the previous day facilitated the recall of food eaten and meal times, study routine, time when the child woke up or went to sleep (Fernandes et al., 2017). This assessment made it possible to quantify food consumption and compare the adequacy of individual needs. In $20 \%$ of the sample, this recall was applied again to validate the information initially collected.

\subsection{Food consumption}

A protocol applied by the Food and Nutritional Surveillance System (SISVAM) was applied, which is a standardized instrument by the Ministry of Health, of food consumption markers for qualitative measurement on the eating habits of the children evaluated. A standard questionnaire model was used and adapted to the conditions of the parents / guardians and children in this study (Sisab, Sisvan Web, own information system).

\subsection{Inclusion and exclusion criteria}

The study included all children aged 6 to 7 years enrolled in three municipal public schools located in the cities of Maceió, Major Isidoro and Palmeira dos Índios in the state of Alagoas. Children of this age group, diagnosed by the school or by the group of psychologists with the presence of some pathology that compromised their cognitive and intellectual functions, were excluded from the research.

\subsection{Statistical analysis}

The data were subjected to descriptive analysis, graphic analysis and the chi-square statistical test in order to determine the influence of the categories concerning the number of cases of echistosomiasis. The Scott-Knott cluster test at $5 \%$ probability was used to verify possible differences between the study sites. All the analyzes were performed using Software Genes (Cruz, 2016).

\section{Results}

\subsection{Sociodemographic characteristics}

Among the students examined, 27 (42.19\%) were from school 1, 23 (35.93\%) from school 2 and 14 (21.88\%) from school 3, thus totaling $100 \%$ of the sample. The age range of students was 06 (45.31\%) and 07 years (59.69\%), with a predominance of females (59.38\%). As for the type of housing, $100 \%$ of the participants live in a masonry house, of which $98.4 \%$ had a bathroom. It was observed that $4.6 \%$ of children were in the habit of bathing in a river or pond and $15.62 \%$ of children had pathologies reported by their parents / guardians (such as parasites). The sociodemographic characteristics of the children of the three schools involved in the research are shown in Graph 1 . When observing the number of residents, brothers, family income, type of housing, number of rooms, bathrooms and education, it appears that there was no significant difference among the evaluated students. The low family income (1 minimum wage) of these children is an aggravating factor in access to better living conditions.

Among the factors associated with the occurrence of diseases in the children of the three schools involved in the research, it was observed that there was no significant difference in relation to basic sanitation, running water, the presence of a toilet, garbage collection, the presence of a smoker, alcoholic beverages and pathologies (Graph 2).

\subsection{Executive functions}

The data obtained in the WISC IV test among students from the three municipalities (Maceió, Major Isidoro and Palmeira dos Índios) are presented in Table 1 . With regard to students from Maceió-AL, (27 participants), the data obtained in the WISC test IV, had the general classification in the 3 subtests below the average. From the data obtained in the TAC test, the average standard score obtained in this test was 109.9 and from the data obtained in the SCC subtest through the average standard score 90.16, the general classification was within the average. The results referring to the participants of Major Isidoro-AL (23 participants), were similar to those observed in Maceió, being below average. Regarding the analysis of the data in the TAC test, the average standard score of 113.1, the classification was pointed out within the average. From the data obtained in the SCC subtest, the standard score examined was 101.1 with a general classification within the average. The results for participants from Palmeira dos Índios-AL (14 participants) were similar to those in other cities, with the classification considered below average.

During the analysis of the data obtained in the TAC test, the average standard score reached was 107.2, thus being generally classified within the average and from the data obtained in the SCC subtest: the general classification was presented within the average, with the standard score of 91.1. Although the children had higher scores for time / 


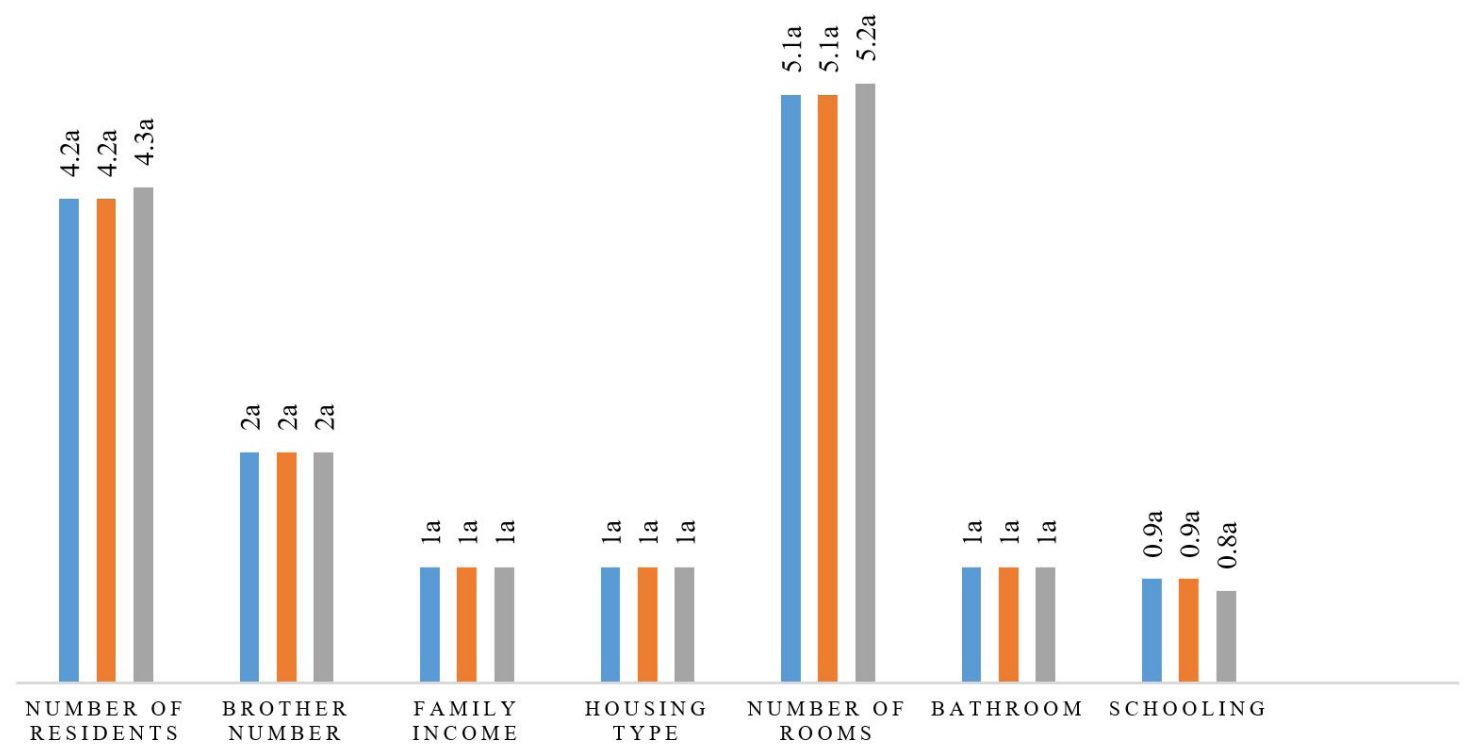

Graph 1. Sociodemographic characteristics of children from the three schools involved in the research, from February to July 2019. Average followed by the same letter do not significantly difer among each Other by the Scott-Knott test $(\mathrm{p}<0.05)$.

- Maceió $\quad$ Major Isidoro $\square$ Palmeira dos Índios

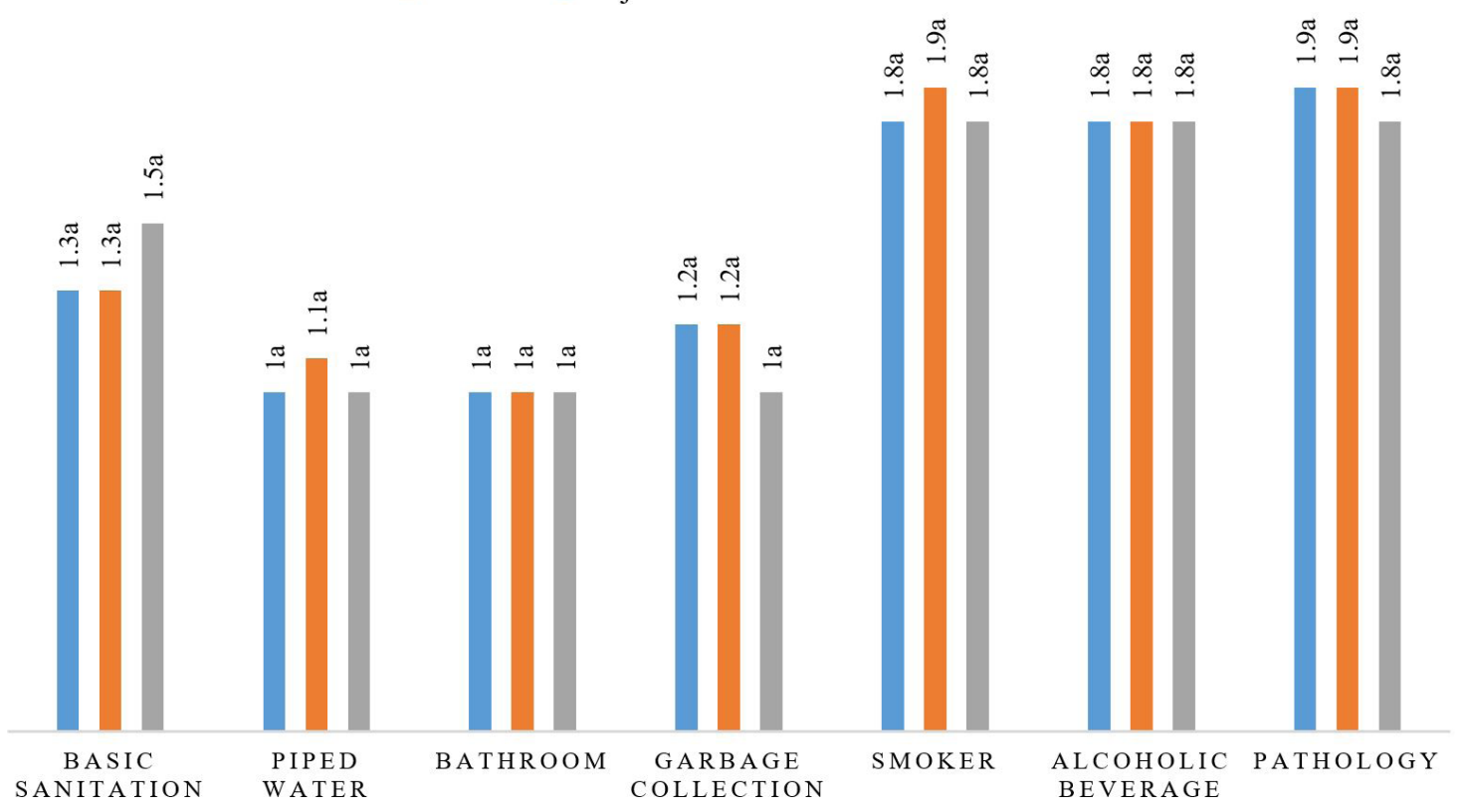

Graph 2. Factors associated with the occurrence of diseases among children from the three schools involved in the research, from February to July 2019. Average followed by the same letter do not significantly difer among each Other by the Scott-Knott test ( $\mathrm{p}<0.05$ ).

errors, there was an inequality in terms of the WISC IV averages. In view of the exposed data, it was found that the scores related to the WISC-IV subtests were classified as below average, which means insufficiency in non-verbal abstract reasoning, ability to concentrate and visual attention. In the TAC and SCC tests, which are related to attention and oral ability in the listening comprehension skill, the participants were classified as average. However, even if the classifications are divided between below average and average, it is possible to identify from the 
subtests of the WISC-IV (assess the Intelligence Quotient), a deficiency that points to a predominance in cognitive level below the average. Neuropsychological monitoring was recommended to participants who showed great difficulties and / or very low scores, so that they could be properly monitored. In view of the exposed data, concerning the 3 schools mentioned, it was found that the scores for the WISC-IV subtests were found to be below average. In the TAC and SCSF tests, the participants were classified as average (Graph 3).

\subsection{Nutritional}

For a better understanding of the amount of data in the graphs, it was decided to divide this assessment into two stages: the anthropometric and the micro and macro nutrients. The anthropometric data collected, diagnosed the students' nutritional status, with no significant differences in results between the cities evaluated (Graph 4). In Maceió the average weight was a little high according to the other cities, with a diagnosis of overweight, with the other cities having children in the eutrophic state. Height for age, found the same results, with no change. All within eutrophy and stature suitable for age. With regard to the BMI percentile, The city of Palmeira dos Índios and Major Isidoro showed more eutrophic children, that is, within the normal range expected for their age. Regarding the consumption of total calories based on the analysis of the children's $24 \mathrm{~h}$ recall, there was not much difference in this caloric consumption. In the city of Maceió, consumption was a little high; with a difference of $46.6 \mathrm{kcal}$ (calories) in relation to the city of Major Isidoro, which met the average of $86.6 \mathrm{kcal}$ (calories). The city of Palmeira dos

Table 1. WISC IV results, concerning students from Maceió, Major Isidoro and Palmeira dos índios, from February to may 2019.

\begin{tabular}{llcc}
\hline \multicolumn{1}{c}{ CITY } & \multicolumn{1}{c}{ SUBTEST } & MEDIAN SCORE & MAIN CLASSIFICATION \\
\hline Maceió & Matrix reasoning (RM) & 7.7 & Low \\
& Digits (DG) & 5.5 & Low \\
& Code A (CD) & 8.1 & Low \\
Major Isidoro & Matrix reasoning (RM) & 6 & Low \\
& Digits (DG) & 7,6 & Low \\
& Code A (CD) & 8,59 & Low \\
Palmeira dos ìndios & Matrix reasoning (RM) & 6,1 & Low \\
& Digits (DG) & 8,9 & Low \\
& Code A (CD) & 6.88 & Low \\
\hline
\end{tabular}

$$
\text { Maceió } \quad \text { Major Isidoro } \quad \text { Palmeira dos Índios }
$$

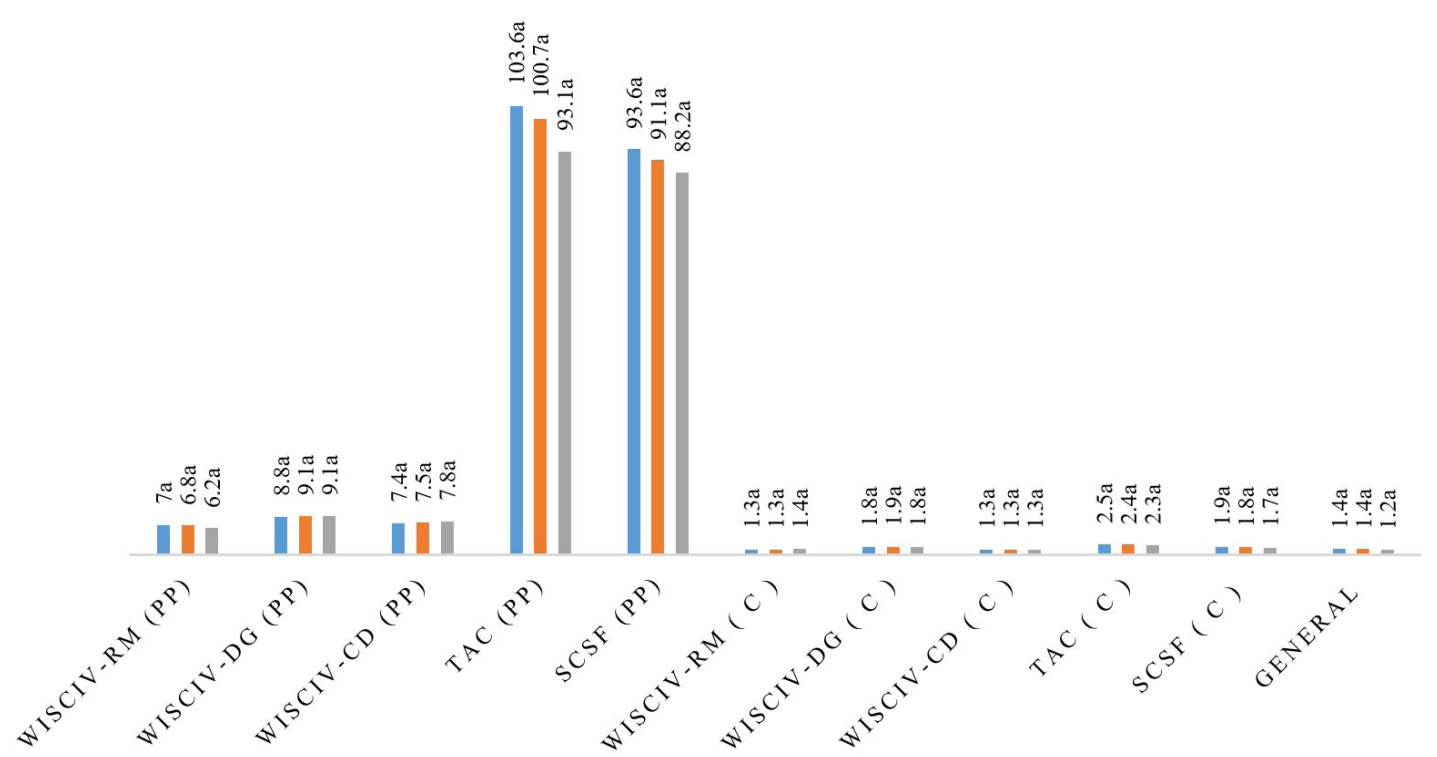

Graph 3. Neuropsychological evaluation of children from the three schools involved in the research, from February to July 2019 . Subtitles PP - Pontos Ponderados; C - ranking; RM - Matrix reasoning; DG - Digits; CD - Codes; TAC - Attention cancel test e SCC -Sequence of spoken sentences. Average followed by the same letter do not significantly difer among each Other by the Scott-Knott test ( $\mathrm{p}<0.05$ ). 
Índios, presented the average with a difference of 40 kcal (calories) between Major Isidoro and its statistical data. Regarding the consumption of Macronutrients, proteins, carbohydrates and lipids, of the cities involved showed the same percentage consumption. With regard to Micronutrients: $\mathrm{Ca}, \mathrm{Fe}, \mathrm{K}, \mathrm{Mg}$ and $\mathrm{Na}$, and vitamins $\mathrm{A}$, C, D, B1, B9 and B12, consumption was similar, without any significant difference (Graph 5).

\section{Discussion}

\subsection{Sociodemographic characteristics}

The average family income of 1 minimum wage, for four people per residence, as shown by the results, creates great economic difficulties for parents / guardians to support their family regardless of the city evaluated. This reflects on the quality of life of the family and especially the child. The economic reality of these families reflects on the eating conditions of these children, and consequently, affects the learning process, causing deficiencies in the development of executive functions, among others. According to the World Health Organization (WHO), poor basic sanitation is a threat to population health, with children being the most affected, especially those 0 to 5 years old, who are in the full stage of educational development. UNICEF and WHO point to diarrhea as the second leading cause of death among children in this age group, reaching the mark of 1.5 million deaths per year worldwide. Fecal-oral transmission diseases, especially diarrhea, represent on average more than $80 \%$ of diseases related to inadequate environmental sanitation (ITB, 2013). Despite the idea that residents with masonry houses should have bathrooms in

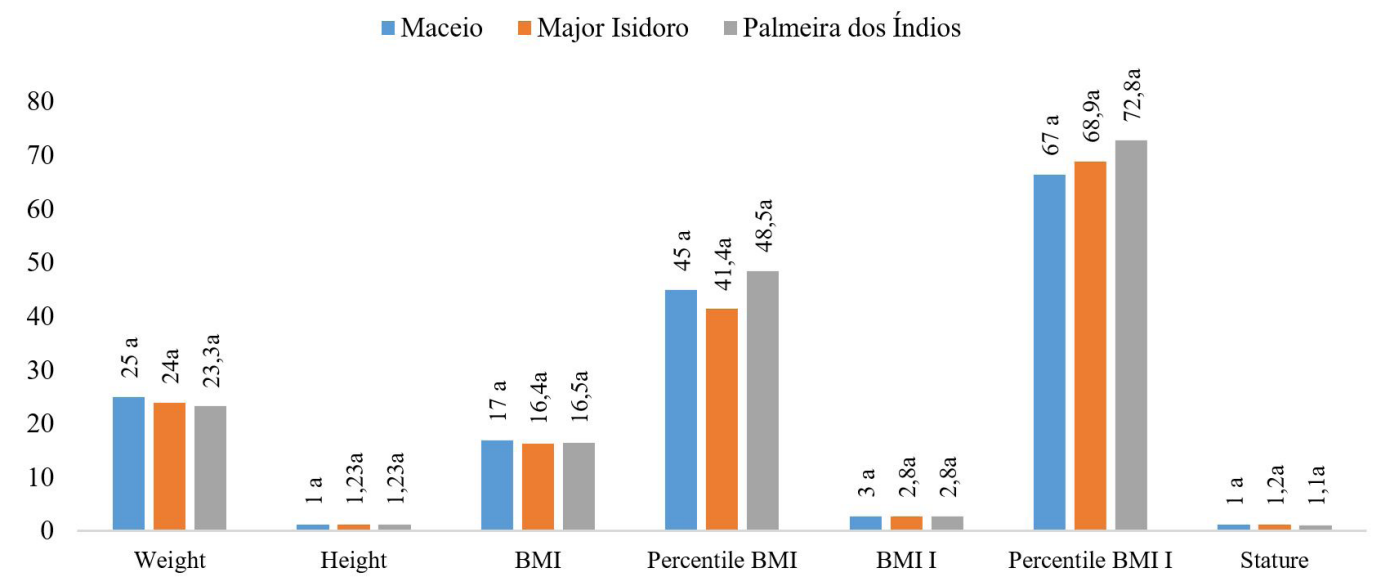

Graph 4. Anthropometric assessment of children from the three schools involved in the research, from February to July 2019. Subtitles: BMI - Body Mass Index and BMI I - Intelligent Body Mass Index. Average followed by the same letter do not significantly difer among each Other by the Scott-Knott test $(\mathrm{p}<0.05)$.

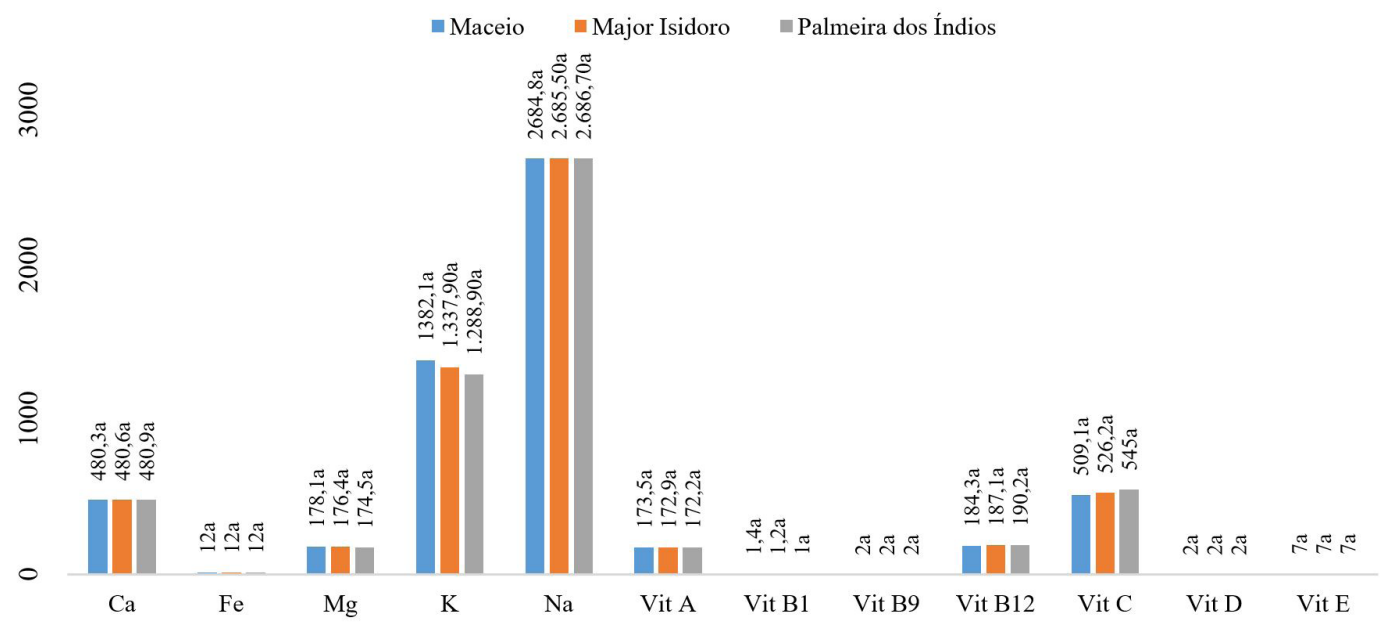

Graph 5. Evaluation of macronutrients and micronutrients (Average), of children from the three schools involved in the research, from February to July 2019. Subtitles: Ca - Calcium; Fe - Iron; Mg - Magnesium; K - Potassium; Na - Sodium; VIT A - Vitamin A; VIT B1 Vitamin B1; Vitamin B9; VIT B12 - Vitamin B12; VIT C - Vitamin C; VIT D - Vitamin D; VIT E - Vitamin E. Average followed by the same letter do not significantly difer among each Other by the Scott-Knott test $(\mathrm{p}<0.05)$. 
their homes, some of them still do not. Most of the times, they take frequent baths in ponds or rivers, for example, causing individuals some episodic pathologies, such as some parasites, and thus affecting their health. Carvalho and De Assis Mendonça (2017), affirm that frequent baths in rivers or lagoons, can present in the subjects positive results of schistosomiasis. With regard to this study, it is noted that the presence of pathology is related to data from bathing rivers / lagoons. Despite the insignificant average of these baths (4.6\%), according to the responses of parents / guardians about the health of their children, there was a total relationship between this habit and the presence of pathologies in children, that is, all children (3) who practiced bathing in rivers / lagoons, had some pathology.

According to the World Health Organization (WHO), environmental sanitation is the art of promoting and recovering health through measures of collective reach and motivation of the population (ITB, 2013). Basic sanitation, on the other hand, is the part of the sanitation of the environment focused on water supply services, disposal of sanitary sewage (conditioning, collection, transportation and disposal of waste), provision of drainage and disposal of waste water (Carvalho; Oliveira, 2003). That is, basic sanitation is one of the ways to contribute to maintaining the balance of nature and human survival itself. A child will only be able to have a good school performance if there are sanitary conditions for his performance (ITB, 2013). As a consequence of the lack of sanitation services, the population's way of life suffers profound influences, which was evidenced in the result of the questionnaires carried out with 111 families residing in communities in the rural area of the Baixo Munim region, according to Mota's research. et al. (2015). The vast majority of respondents (75\%) do not perform any treatment on the water they consumed, and the remaining $25 \%$ perform inadequate procedures such as using outdated filters. It was also found that $90 \%$ used rudimentary septic tanks or buried human waste, with $10 \%$ depositing effluents directly into rivers and / or streams, which are most often used as a source of water supply (Mota, 2014).

\subsection{Executive functions}

In many studies, WISK IV is an instrument used as a guide for the analysis, which assesses from cognitive deficits originating from sickle cell anemia (Stotesbury et al., 2018), as well as others regarding quality of life with health and neurocognitive results that point out its usefulness for obtaining reliable results (Sorensen et al, 2018). We chose to include it in this study, due to the subtests investigating the characteristics of the children's executive functions, as well as the use of SEABRA tests such as TAC, which help to subsidize inferences about the participants' concentrated, alternate and divided attention, as stated by Dias et al. (2009), about TAC in their studies. According to Adolph and Franchak (2017), the child's development is related to neurotransmitters. Their understanding of the world permeates the individual's perception of himself. This is also done through your movements. It is perceived that the individual needs favorable conditions for cognitive development: whether from motor or auditory development, as stated by Ilari (2014), and olfactory as Iatropoulos, et al. (2018). The way the subject interacts with the external environment, can accelerate, or delay his cognitive development with his whole body connected to the mind. Such connections are linked to perception, memory, information processing, etc.

Through the exposed data, concerning the 3 schools studied, it was found that the scores related to the WISC-IV subtests were below average. In the TAC and SCC tests, the participants scored in the average. However, even though the classifications are divided between below average and average, it is possible to identify from the subtests of WISCIV, that the general IQ showed a cognitive level below the average. In some studies, as pointed out by Shanahan et al. (2006), the literature has shown controversial results with the combination of tests and participants, including those related to information processing speed. According to Dias et al. (2011), in their studies on executive functions in preschool children about the development of selective attention measured through TAC, showed results where it was possible to verify an increase in correct answers depending on age progression. It can be seen that for the age group of this research, which is intended for the application of this test, the TAC pointed to an increase in the average of the general scores, despite the general average in the sum of all the tests used still being at a low level cognitive. Regarding speech, listening, that is, phonological skills, Lima (2018) relate them to the attentional and executive performance, where they both influence each other, which is shown in the SCSF test. Neuropsychological monitoring was recommended to participants who showed considerable difficulties and / or very low scores. The 3 cities had the average age of the participants of 6.8 , being children from 6 to 7 years old and the sex of $1.6 ; 1$ for boys and 2 for girls.

\subsection{Nutritional assessment}

The anthropometric data collected, diagnosed the nutritional status of students and between the cities evaluated, and there were no significant differences between the results. Lopes et al. (2015) in a correlated study with 44 children, mentions children who also presented adequate weight when comparing with their age (86.36\%), however, a small percentage (13.64\%) was diagnosed with risk of overweight. Regarding the consumption of total calories based on the analysis of the children's $24 \mathrm{~h}$ recall, there was not much difference in this caloric consumption between the schools evaluated, and regarding the consumption of macronutrients (proteins, carbohydrates and lipids), the same consumption was found percentage. In the studies by Lopes et al. (2015), the values observed in children, were 462.10 mcg for males and $470.6 \mathrm{mcg}$ for females, for iron the value was $1.7 \mathrm{mg}$, which is lower than recommended by the PNAE. In the present study, the mean for iron was $12 \mathrm{mg}$. Unlike the results observed in this work, Castro et al. (2005), when studying 80 children aged 2 to 5 years, reported that $75.7 \%$ of children had ingestion of macronutrient intake below the recommendation, as well as Lopes et al. (2015) 
when evaluating 44 children. Adequate energy intake is essential for the typical developmental course of children, a deficiency in this intake can cause problems related to executive functions, among other changes. Foods such as meat and dairy products can help remedy this condition. Cavalcante et al. (2006), inferred that the risk of being overweight as a child is worrying because such diagnosis can persist in adulthood, resulting in hypertension, diabetes, among others.

Through the exposed data, it is noted the relevance of further investigations on this theme, in greater scope and that may include other municipalities in Alagoas. The concern with the socio-environmental conditions in which children from Alagoas live is growing and taking shape, due to the losses that can arise in the nutritional state and in children's learning. The results allowed to observe that there was no difference between the students of the three municipalities, probably these children have similar social conditions. Thus, considering the results found, the importance of integrating future projects to reverse the diagnosis presented and even to make correlations between such characteristics is highlighted. It is worth noting that the study in question is one of the numerous possible cuts on the study concerning the characteristics of socio-environmental aspects, executive and nutritional functions, which ran through three areas of the state of Alagoas: coast; wild and sertão. Therefore, with the results of this study, it is intended to contribute to future investigations on this topic and to emphasize the pertinence of its inferences mentioned and listed until then.

\section{References}

ADOLPH, K.E. and FRANCHAK, J.M., 2017. The development of motor behavior. Wiley Interdisciplinary Reviews: Cognitive Science, vol. 8, no. 1-2, pp. e1430. http://dx.doi.org/10.1002/ wcs.1430. PMid:27906517.

BAGGETTA, P. and ALEXANDRER, P.A., 2016. Conceptualization and operationalization of executive function. Mind, Brain, and Education, vol. 10, pp. 10-33.

BARDIKOFF, N. and SABBAGH, M., 2017. The differentiation of executive functioning across development: Insights from developmental cognitive neuroscience. In: N. BUDWIG, P. ZELAZO, eds. New Perspective on Human Development. New York, NY: Cambridge University Press.

BRASIL, 2011 [viewed 10 August 2018]. Programa das Nações Unidas para o desenvolvimento do Brasil [online]. Available from: http:// www.br.undp.org/

BRASIL, 2013 [viewed 10 August 2018]. Atlas do Desenvolvimento Humano no Brasil [online]. Available from: http://www. atlasbrasil.org.br

CARVAlHO, A. and OLIVEIRA, M., 2003. Princípios básicos do saneamento do meio. São Paulo: SENAC.

CARVALHO, M. and DE ASSIS MENDONÇA, F., 2017. Condicionantes socioambientais do modelo (re) produtivo da esquistossomose na região endêmica do município de Aracaju/SE. Hygeia, vol. 13, no. 24, pp. 70-91.

CASTRO, T.G., NOVAES, J.F., SILVA, M.R., COSTA, N.M.B., FRANCESCHINI, S.C.C., TINÔCO, A.L.A. and LEAL, P.F.G., 2005. Caracterização do consumo alimentar, ambiente socioeconômico e estado nutricional de pré-escolares de creches municipais de Viçosa, MG. Revista de Nutrição, vol. 18, no. 3, pp. 321-330. http://dx.doi.org/10.1590/S1415-52732005000300004.

CAVALCANTE, A.A.M., TINÔCO, A.L.A., COTTA, R.M.M., RIBEIRO, R.C.L., PEREIRA, C.A.S. and FRANCESCHINI, S.C.C., 2006. Consumo alimentar e estado nutricional de crianças atendidas em serviços públicos de saúde do município de Viçosa, Minas Gerais. Revista de Nutrição, vol. 19, no. 3, pp. 321-330. http:// dx.doi.org/10.1590/S1415-52732006000300003.

CAVALHEIRO, M., SANTOS, R.B., SOUZA, J.C., SOMMER, R.M., SOARES, R.C. and SANTOS, L.P., 2020. Avaliação nutricional infantil. In: Anais do Salão Internacional de Ensino, Pesquisa e Extensão, vol. 9, no. 2, pp. 1-6.

CRUZ, C.D., 2016. Genes Software-extended and integrated with the R, Matlab and Selegen. Acta Scientiarum. Agronomy, vol. 38, no. 4, pp. 547-552. http://dx.doi.org/10.4025/actasciagron. v38i3.32629.

DIAS, N.M., 2009. Avaliação neuropsicológica das funções executivas: tendências desenvolvimentais e evidências de validade de instrumentos. São Paulo: Universidade Presbiteriana Mackenzie, 250 p. Dissertação de Mestrado em Distúrbios do Desenvolvimento.

DIAS, N.M.; TREVISAN, B.T.; PRADO, J.M., 2011. Funções executivas em crianças pré-escolares: Desenvolvimento da atenção seletiva medida pelo Teste de Atenção por Cancelamento. Cadernos de Psicopedagogia, p. 1-16.

DONALD, K.A., HOOGENHOUT, M., DU PLOOY, C.P., WEDDERBURN, C.J., NHAPI, R.T., BARNETT, W., HOFFMAN, N., MALCOLM-SMITH, S., ZAR, H.J. and STEIN, D.J., 2018. Drakenstein child health study (DCHS): investigating determinants of early child development and cognition. BMJ Paediatrics Open, vol. 2, no. 1, pp. 282. http:// dx.doi.org/10.1136/bmjpo-2018-000282. PMid:29942867.

ELKIND, D., 1957. Crianças e adolescentes. Ensaios interpretativos sobre Jean Piaget. São Paulo: Zahar.

FERNANDES, C.S., MARQUES, G., FESTAS, G., FERREIRA, F., SILVA, C., 2017. Revisão integrativa sobre instrumentos de avaliação de consumo alimentar em crianças em idade escolar. Cogitare Enferm., vol. 22, no. 4, pp. e49875.

IATROPOULOS, G., HERMAN, P., LANSNER, A., KARLGREN, J., LARSSON, M. and OLOFSSON, J.K.. 2018. The language of smell: connecting linguistic and psychophysical properties of odor descriptors. Cognition, vol. 178, pp. 37-49. http://dx.doi.org/10.1016/j. cognition.2018.05.007. PMid:29763790.

ILARI, B., 2014. Bebês também entendem de música: a percepção e a cognição musical no primeiro ano de vida. Revista da ABEM, vol. 7, pp. 83-90.

INSTITUTO TRATA BRASIL - ITB, 2013 [viewed 10 August 2018]. Esgotamento sanitário inadequado e impactos na saúde da população [online]. São Paulo: ITB. Available from: http://www. tratabrasil.org.br/datafiles/uploads/drsai/esgotamento.pdf

JOMBO, G.T. and DABIT, O.J., 2018. The growing IDPS in the country and impact on childhood malnutrition: averting a future generation with stunted growth and knowledge. Journal of BioMedical Research E Clinical Practice, vol. 1, no. 2, pp. vii-viii. http://dx.doi.org/10.46912/jbrcp.64.

LIMA, C. S., 2018. Efeitos neuropsicológicos da exposição ao mercúrio em crianças e adolescentes da região do rio Madeira-Rondônia. Salvador: Instituto de Psicologia. Dissertação de Mestrado em Psicologia do Desenvolvimento Humano.

LOPES, J. M., ZANELATO, E. F. N., ROCHA, S. A. M. T., FONSECA, C. S. and ALVES, R. D. M., 2015. Avaliação da adequação de ferro, cálcio, vitamina a e vitamina c da merenda ofertada a préescolares em um centro educacional público de Viçosa, MG. Anais Simpac, vol. 7, no. 1, pp. 100-105. 
MONDINI, L. and GIMENO, S.G.A., 2011. Transição nutricional: significado, determinantes e prognóstico. In: J.A. TADDEI, R.M.F. LANG, G. LONGO-SILVA and M.H.A. TOLONI, eds. Nutrição em saúde pública. Rio de Janeiro: Editora Rubio Ltda, pp. 561-575.

MONTEIRO, C.A., BENICIO, M.H., KONNO, S.C., SILVA, A.C., LIMA, A.L.L. and CONDE, W.L., 2009. Causas para o declínio da desnutrição infantil no Brasil, 1996-2007. Revista de Saude Publica, vol. 43, no. 1, pp. 35-43. http://dx.doi.org/10.1590/ S0034-89102009000100005. PMid:19169574.

MOTA, J.J.P., 2014. Saneamento básico e seu reflexo nas condições socioambientais da zona rural do Baixo Munim - MA. São Luis: Programa de Pós-Graduação em Desenvolvimento Socioespacial e Regional da Universidade Estadual do Maranhão, 103 p. Dissertação de Mestrado em Desenvolvimento Socioespacial e Regional.

SANOU, A.S., DIALLO, A.H., HOLDING, P., NANKABIRWA, V., ENGEBRETSEN, I.M.S., NDEEZI, G., TUMWINE, J.K., MEDA, N., TYLLESKÄR, T. and KASHALA-ABOTNES, E., 2018. Association between stunting and neuro-psychological outcomes among children in Burkina Faso, West Africa. Child and Adolescent Psychiatry and Mental Health, vol. 12, no. 1, pp. 30. http://dx.doi. org/10.1186/s13034-018-0236-1. PMid:29930702.

SEABRA, A. and DIAS, N., 2012a. Avaliação neuropsicológica cognitiva: Atenção e funções executivas. São Paulo: Memnon, vol. 1.

SEABRA, A. and DIAS, N., 2012b. Avaliação neuropsicológica cognitiva: linguagem oral. São Paulo: Memnon, vol. 2.

SHANAHAN, M.A., PENNINGTON, B.F., YERYS, B.E., SCOTT, A., BOADA, R., WILLCUTT, E.G., OLSON, R.K. and DEFRIES, J.C., 2006. Processing speed deficits in attention deficit/hyperactivity disorder and reading disability. Journal of Abnormal Child
Psychology, vol. 34, no. 5, pp. 585-602. http://dx.doi.org/10.1007/ s10802-006-9037-8. PMid:16850284.

SORENSEN, L. G., NEIGHBORS, K., HARDISON, R. M., LOOMES, K. M., VARNI, J. W., NG, V. L., SQUIRES, R. H. and ALONSO, E. M. and PEDIATRIC ACUTE LIVER FAILURE STUDY GROUP, 2018. Health related quality of life and neurocognitive outcomes in the first year after pediatric acute liver failure. The Journal of Pediatrics, vol. 196, pp. 129-138. http://dx.doi.org/10.1016/j. jpeds.2018.01.030.

STOTESBURY, H., KIRKHAM, F.J., KÖLBEL, M., BALFOUR, P., CLAYDEN, J.D., SAHOTA, S., SAKARIA, S., SAUNDERS, D.E., HOWARD, J., KESSE-ADU, R., INUSA, B., PELIDIS, M., CHAKRAVORTY, S., REES, D.C., AWOGBADE, M., WILKEY, O., LAYTON, M., CLARK, C.A. and KAWADLER, J.M., 2018. White matter integrity and processing speed in sickle cell anemia. Neurology, vol. 90, no. 23, pp. e2042-e2050. http://dx.doi.org/10.1212/ WNL.0000000000005644. PMid:29752305.

TERRA, M.R., 2010 [viewed 10 August 2018]. O desenvolvimento humano na teoria de Piaget [online]. 2010. Available from: https:// pt.scribd.com/document/310717284/O-DesenvolvimentoHumano-Na-Teoria-de-Piaget

TURAB, A., SOOFI, S. B., AHMED, I., BHATTI, Z., ZAIDI, A. K. M. and BHUTTA, Z. A., 2014. Demographic, socioeconomic, and health characteristics of the MAL-ED network study site in rural Pakistan. Clinical Infectious Diseases, vol. 59, suppl 4, pp. S304-S309. http://dx.doi.org/10.1093/cid/ciu391.

WECHSLER, D., 2013. Escala Weschsler de inteligência para crianças: WISC-IV. 2013. Manual Técnico. Tradução do manual original Maria de Lourdes Duprat. 4. ed. São Paulo: Casa do Psicólogo. 